\title{
Breast Cancer pNO(i+) TNM Finding v8
}

National Cancer Institute

\section{Source}

National Cancer Institute. Breast Cancer pNO(i+) TNM Finding v8. NCI Thesaurus. Code C139431.

Breast cancer with IT Cs only (malignant cell clusters no larger than $0.2 \mathrm{~mm}$ ) in regional lymph node(s). (from AJCC 8th Ed.) 